\title{
8
}

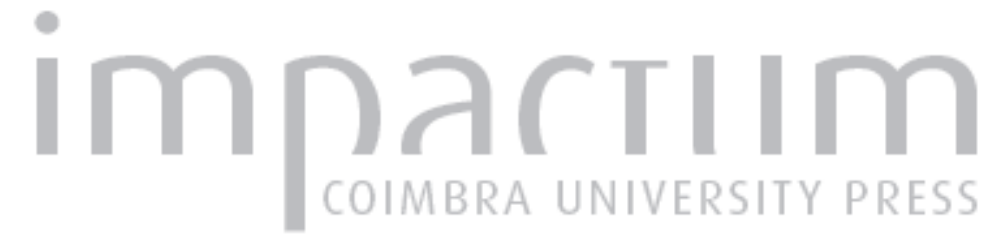

\section{Sobre a filosofia da arte de Antero}

Autor(es): Pita, António Pedro

Publicado por: Imprensa da Universidade de Coimbra

URL persistente:

URl:http://hdl.handle.net/10316.2/43741

DOI:

DOI:https://doi.org/10.14195/2183-8925_13_4

Accessed : $\quad$ 26-Apr-2023 03:48:37

A navegação consulta e descarregamento dos títulos inseridos nas Bibliotecas Digitais UC Digitalis, UC Pombalina e UC Impactum, pressupõem a aceitação plena e sem reservas dos Termos e Condições de Uso destas Bibliotecas Digitais, disponíveis em https://digitalis.uc.pt/pt-pt/termos.

Conforme exposto nos referidos Termos e Condições de Uso, o descarregamento de títulos de acesso restrito requer uma licença válida de autorização devendo o utilizador aceder ao(s) documento(s) a partir de um endereço de IP da instituição detentora da supramencionada licença.

Ao utilizador é apenas permitido o descarregamento para uso pessoal, pelo que o emprego do(s) título(s) descarregado(s) para outro fim, designadamente comercial, carece de autorização do respetivo autor ou editor da obra.

Na medida em que todas as obras da UC Digitalis se encontram protegidas pelo Código do Direito de Autor e Direitos Conexos e demais legislação aplicável, toda a cópia, parcial ou total, deste documento, nos casos em que é legalmente admitida, deverá conter ou fazer-se acompanhar por este aviso.

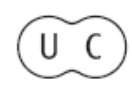


REVISTA DE HISTÓRIA DAS IDEIAS 13

\section{Antero de Quental}

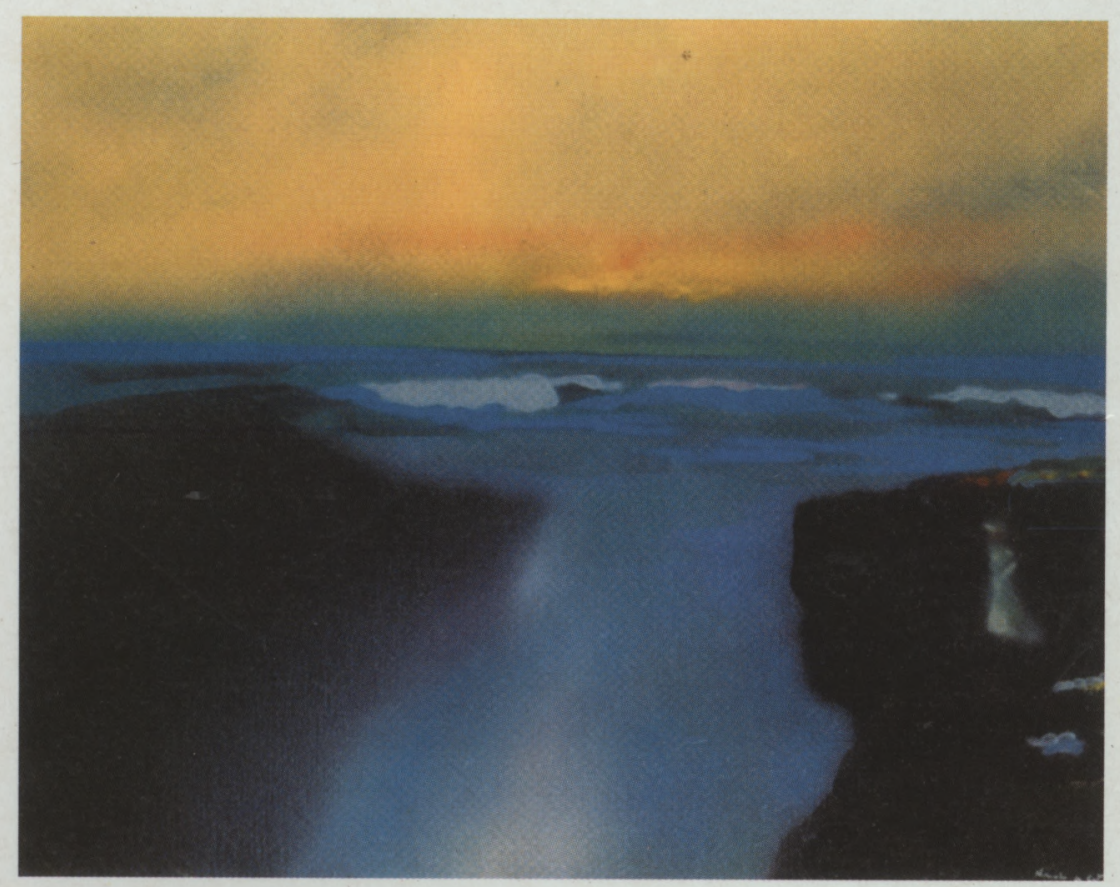

INSTITUTO DE HISTÓRIA E TEORIA DAS IDEIAS FACULDADE DE LETRAS

COIMBRA 1991 


\section{SOBRE A FILOSOFIA DA ARTE DE ANTERO}

A análise, empreendida por Antero, de Os Lusíadas: ensaio sobre Camões $e$ a sua obra, em relação à sociedade portuguesa e ao movimento da Renascença de Oliveira Martins e de Teoria da História da Literatura Portuguesa de Teofilo Braga excede substancialmente os limites da recensão ou da crítica. Por isso, acrescentada das considerações em torno de Desenvolvimento da Literatura Portuguesa de M. Pinheiro Chagas, é publicada em separata, no mesmo ano de $1872 \mathrm{em}$ que apareceram as referidas obras e em que ela própria apareceu nas páginas de $O$ Primeiro de Janeiro.

No ano anterior ocorrera a grande polémica em torno da iniciativa e proibição das Conferências do Casino e aparecera o opúsculo $O$ que é a Internacional. Em 1872, Antero apresenta e presta colaboração à revista $O$ Pensamento social. E é neste contexto particularmente polémico - ou politicamente determinado - que Antero de Quental escreve Considerações sobre a Filosofia da História Literária Portuguesa (a propósito de alguns livros recentes). Enquanto análise, que indiscutivelmente é, o texto não nos vai ocupar muito. O seu maior interesse, para o objectivo deste artigo, reside na trama conceitual que subjaz à leitura crítica realizada e à clareza com que Antero procura desenvolver, a propósito de um objecto preciso, o desenho geral de uma filosofia da revolução e ao lugar, intrinsecamente contraditório, ocupado pela arte nessa filosofia.

É no mesmo gesto teórico, de facto, que Antero sublinha os dois

\footnotetext{
* Faculdade de Letras da Universidade de Coimbra.
} 
aspectos capitais da filosofia e da estética progressivas: a historicidade global das manifestações humanas e a crítica da noção de génio. A ideia de uma filosofia da história literária está pois dependente da ideia de uma filosofia da história, isto é, da consideração de que a humanidade é um todo em devir e que este devir humano realiza progressivamente uma finalidade, que é a síntese de todo o processo.

São estas as condições epistemológicas requeridas por uma "história crítica, íntima, psicológica" $\left.{ }^{1}\right)$. A relação com a história, por conseguinte, é menos da ordem do julgamento que da compreensão. E é porque o indivíduo constitui, "dentro da humanidade, uma força, não caprichosa, mas coerente, embora livre, e cujas manifestações são todas respeitáveis e legítimas, tendo todas a sua razão de ser e o seu valor" - é por isto que nenhuma prática artística pode ser entendida "como uma criação meramente individual" ( ${ }^{2}$ ) e que toda a análise da obra de arte deve ser também a análise das suas condições de produção.

Em suma: há em todo o discurso estético uma estática e uma dinâmica; é a estática, "toda abstracta", que "explica e dá a razão" da dinâmica; é porém a dinâmica "quem explica e dá a razão das obras de arte, naturalmente concretas e contidas nas condições do tempo e do meio" ( $\left.{ }^{3}\right)$.

Está fundada a mudança de critério da inteligibilidade da obra de arte. "Considerava-se, há 100 anos ainda (sublinha Antero), a obra literária como criação meramente individual, determinada apenas pelo sentimento pessoal, o génio, as disposições do poeta: não se via a relação estreita que há entre a inspiração do indivíduo e o pensamento da época, a raça, o meio social e o momento histórico" $\left({ }^{4}\right)$.

O olhar da historicidade, e só ele, permite captar para além da obra e suas diferenças, o plano mais profundo da irredutibilidade de experiências estéticas diferentes. Com esta mudança de olhares, a obra de arte deixou de referir-se ao clássico tomado como paradigma e passa a referir-se à experiência de que é concretização, passa a existir, nas palavras de Antero, como "revelação do sentir íntimo dos homens nas

(') Antero de Quental, "Consideraçōes sobre a filosofia da história literária portuguesa", in Prosas, vol. II, Coimbra, Imprensa da Universidade, 1926, p. 209.

( ${ }^{2}$ Idem, ibidem, p. 209.

( ${ }^{3}$ Idem, ibidem, p. 210.

(4) Idem, ibidem, p. 210. 
diversas condições morais e sociais" $\left({ }^{5}\right)$.

S6 uma concepção historicizada pode, então, discernir - ou melhor: conceber - a ideia de uma utilidade filosófica, social ou política da arte porque só tomando-a como horizonte teórico a arte transcende os limites da individualidade e do gosto. Escreve Antero: "a filosofia da história encontrou nelas [nas literaturas] o instrumento mais delicado e, ao mesmo tempo, mais preciso, para determinar o grau de valor moral de cada civilização: na sua mão, um poema pode tornar-se, muitas vezes, o ramo de ouro da sibila, com que descesse à região dos mortos, a interrogá-los; versos cantados há mil, há dois e três mil anos, por poetas desconhecidos, explicaram os movimentos das raças, as origens, os esplendores, as revoluções e as catástrofes dos impérios" ( $\left.{ }^{6}\right)$.

Utilidade da obra de arte é, neste contexto teórico, sinónimo de revelação. A arte é a mediação indispensável para a inteligibilidade do movimento das sociedades e do pensamento - "do sentir íntimo" - dos indivíduos. Num duplo sentido: quer no que é efectivamente realizado quer no que é visado simplesmente. Ponto nuclear nesta concepção anteriana: a afirmação da historicidade da experiência estética - e não só da obra de arte - permite apreender a possibilidade e o limite; como escreve Antero, "essas obras supremas dizem-nos ao mesmo tempo o que um povo foi e o que quis ser, decobrem-nos a sua aspiração íntima e marcam os limites dentro dos quais the foi dado realizá-la" ()).

Assim, a definitiva aquisição da consciência histórica abre o caminho, do mesmo passo, à superação da doutrina do génio, à descoberta de uma abertura individual irredutível do homem para o mundo-aqui designada por experiência-, à valorização ôntica da obra de arte e à consideração positiva da noção de limite.

Há, nesta concepção de utilidade da arte, uma transformação substancial relativamente à noção de utilidade combativa. A releitura da "Nota sobre a missão revolucionária da poesia", publicada nas Odes Modernas (1865), é elucidativa quanto à valorização dos temas dominantes. É certo que uma das teses centrais destas páginas célebres afirma: "a Poesia é a confissão sincera do pensamento mais íntimo de uma idade", depois reescrita como "a Poesia moderna é a voz da

(5) Idem, ibidem, p. 210, subl. meu.

(') Idem, ibidem, p. 211.

(7) Idem, ibidem, p. 225 
revolução" ${ }^{(8)}$. Mas não me parece menos clara a importância desta outra afirmação quase idêntica: "a Poesia que quiser corresponder ao sentir mais fundo do seu tempo, hoje, tem forçosamente de ser uma poesia revolucionária. Que importa que a palavra não pareça poética às vestais literárias do culto da arte pela arte?" $\left({ }^{9}\right)$.

Sublinho: "a poesia que quiser corresponder". Se só revolucionária a poesia que seja a voz do seu próprio tempo, solicita-se todavia um esforço para a adequação do texto poético às exigências do tempo. A adequação não é espontânea: é necessário um esforço para romper com os dispositivos estéticos vigentes e para inscrever, no novo texto, as circunstâncias novas. Enquantoé explicitamente requerido, este esforço significa que a correspondência entre a obra de arte e a situação histórica não é imediata mas precisamente mediada pela afirmação de uma vontade, isto é, pelo poder de uma subjectividade. Podemos dizer: a poesia revolucionária é obra de uma subjecti vidade, a correspondência entre a obra e o tempo é afirmada por um sujeito mediador.

Os elementos fundamentais de uma poética anteriana começam a estar recenseados. Encontramo-los, por exemplo, no artigo consagrado às Meditações poéticas de Lamartine e nos dois textos dedicados a João de Deus.

Quais são esses elementos? O primeiro diz respeito à inovação realizada por Lamartine: "sou o primeiro, escreveu o poeta francês no prefácio de 1849 a Meditações poéticas, a ter feito descer a poesia do Parnaso, e a dar ao que chamava Musa, em lugar de uma convencional lira de sete cordas, as próprias fibras do coração humano, vibradas e comovidas pelas inumeráveis emoções da alma e da natureza". Trata-se, em rigor, do acto de nascimento da poesia lírica, que destitui a mitologia, a convenção e o artifício e faz do homem o instrumento da poesia pela afirmação simultânea doeu como aquele que toca o instrumento e aquele que é esse instrumento $\left({ }^{10}\right)$. Trata-se de uma afirmação fundamental, esta do homem como "instrumento sonoro de sensações, sentimentos e ideias". A formulação pertence também a Lamartine: "o homem sensitivo e pensante é um instrumento sonoro de sensações,

$\left(^{8}\right)$ Idem, "Nota sobre a missão revolucionária da Poesia", in Prosas, vol. I, Coimbra, Imprensa da Universidade, 1923, p. 306.

$\left.{ }^{9}\right)$ Idem, ibidem, p. 314.

$\left.{ }^{10}\right)$ Cf. Jean-Marie Gleize, Poésie et figuration, Paris, Editions du Seuil, 1983, p. 29. 


\section{A filosofia da Arte de Antero}

sentimentos e ideias. Cada corda deste instrumento montado pelo criador, experimenta uma vibração e emite um som proporcional à emoção que a natureza sensível do homem imprime ao seu coração ou ao seu espírito, pela comoção mais ou menos forte que recebe das coisas exteriores ou interiores". É nesta concepção que enraíza a tese da congenialidade, ou antes, da intercomunicação, "o laço misterioso que prende pela simpatia e pelo pensamento duas almas congeniais" $\left({ }^{11}\right)$.

$\mathrm{Na}$ expressão de Lamartine, a correspondência entre os dois pares, sensitivo/pensante e coração/espírito, subjaz à noção de que o homem é capaz de poesia na medida em que é corpo sensível, susceptível de emoção e de comoção, de frisson e de vibração, portanto, finalmente, de música. Portanto, distinguem-se três momentos ficticiamente sucessivos: o corpo cantante, o corpo vibrante, emocionado, à beira da expressão, e o corpo instrumento, tocado; depois, a acção do corpo sobre a língua, a movimentação da língua que vai produzir a língua vibrante, emocionada; enfim, o poema manifestando a língua em acção, e manifestado por ela, vai agir sobre o corpo do destinatário de poesia: o corpo do leitor deve idealmente vibrar ao mesmo ritmo que o corpo vibrante do poeta $\left({ }^{12}\right)$.

É a esta comunicação completa que Anteroé mais sensível no artigo que consagra a Lamartine. E é precisamente ao ser considerada completa, definindo um espaço sem exterior, que a poesia mostra a tensão imanente, afinal, a qualquer prática artística: porque ela é, por outro lado, em última instância um discurso de afirmação de uma transcendência, ao mesmo tempo sua condição essencial. É por isso que a poesia é voz: "os grandes poetas são a voz da humanidade no período em que vivem" $\left({ }^{13}\right)$. Mas é também por isso que esta voz só existe enquanto manifesta, explicita, faz ascender à ordem da dizibilidade tudo o que, sem ela, permaneceria no plano indizível da "afinidade misteriosa entre o homem e a época" $\left({ }^{14}\right)$.

Há um ponto obscurecido nesta questão e cuja importância a obra posterior de Antero se encarregará de sublinhar. O poeta, nas páginas

(") Antero de Quental, "As Meditações poéticas de Lamartine", in Prosas, vol. I, p. 70.

( $\left.{ }^{12}\right)$ C.f. J.-M. Gleize, ob. cit., p. 30.

(13) Antero de Quental, ob. cit., p. 66.

(14) Idem, ibidem, p. 68. 
a que aludo, é um facto: há poetas e "quanto mais poetas são tanto mais profundo se lhes arreiga [o amor] no coração, porque possuem maior sensibilidade" $\left({ }^{15}\right)$. Mas esta dimensão factual (há poesia porque há poetas e há poetas porque há almas mais sensíveis), durante algum tempo exclusiva, será atravessada, com uma insistência cada vez maior, por uma interrogação radical acerca de si própria: porque é que o mistério quer ser dito, porque é que existe a vontade da expressão $\mathrm{e}$ não só a experiência do silêncio?

No artigo "A propósito dum poeta", consagrado a João de Deus, onde o problema vibra com uma intensidade correspondente à sua irresolução, há uma concepção da escrita poética que liga a imperatividade e a espontaneidade. Poeta é o que sente "em si a necessidade fatal de exprimir em cantos tudo o que lhe vai dentro", é o que "diz o que sente na forma que lhe brota espontânea na ideia, fala a linguagem do seu coração" $\left({ }^{16}\right)$. Não é tanto pela reafirmada tese do poeta como instrumento que este artigo nos interessa. É, em primeiro lugar, pelo reforço da tese provocado pela reiterada afirmação da espontaneidade da poesia - isto é, pelo repúdio da específica mediatidade do trabalho poético; esquecer os modelos "para só escutar o que o coração dita" $\left({ }^{17}\right)$, e assim ser natural - pois ser natural, "supremo preceito" $\left({ }^{18}\right)$, é sinónimo de ser verdadeiro (ou melhor, ser verdade) -, constitui o núcleo de toda a legislação poética. Há, é certo, uma oscilação teórica: a espontaneidade é, por vezes, confrontada com a ideia de que a poesia é uma escrita. Quando retoma o preceito de Chatterton, por exemplo, "poeta porque se fez, cantando porque é uma necessidade (escrever porque é preciso, dizia Chatterton)" $\left({ }^{19}\right)$, registamos a curiosa ondulação do canto e da escrita. Mas Antero já escrevera, linhas atrás, o seguinte: "a poesia, a grande, a verdadeira poesia, a que se escreve com uma mão sobre o coração, sem querer outros modelos além da natureza, outras leis mais que a da razão, essa vive e chega longe nos séculos" $\left({ }^{20}\right)$. Dito por outras palavras: toda a

('5) Idem, ibidem, p. 70.

$\left({ }^{16}\right)$ Idem, "A propósito dum poeta", in Prosas, vol. I, p. 97.

( ${ }^{17}$ ) Idem, ibidem, p. 97.

( ${ }^{18}$ Idem, ibidem, p. 98

$\left({ }^{19}\right)$ Idem, ibidem, p. 97.

$\left({ }^{20}\right)$ Idem, ibidem, p. 96. 
poesia é uma escrita mas só há escrita poética auscultando, num corpo que sente, aquilo mesmo que religa esse corpo ao próprio mistério do sentimento. Escrever com uma mão sobre o coração significa prender a escrita, por intermédio do enigma do sentimento, à própria obscuridade não de quem sente mas do que é sentido, do que, ao dar-se, é condição para que o sentimento exista. É neste sentido que a escrita é uma explicitação mas é principalmente uma tradução, quase uma transcrição: e, por isso, escrever (a) verdade é ser natural, é reduzir a marca do trabalho poético até ao limite da transcrição - "poeta porque se fez, cantando porque é uma necessidade (escrever porque é preciso, dizia Chatterton) crendo na poesia como sacerdócio, não como ofício, esquecendo modelos para só escutar o que o coração lhe dita: poeta da verdade, da natureza, esse mais raro é" $\left.{ }^{21}\right)$.

A imediatidade da escritaé, aliás, uma condição para a imediatidade da leitura: permite que o círculo de comunicação efectivamente se realize. E é o segundo aspecto por que este artigo nos interessa. Porque se desprende da sua doutrina a importância política, ou pelo menos social, da poesia: "a poesia é o meio por onde se comunicam as almas; é preciso também ser claro para que se entendam" $\left({ }^{22}\right)$. Antero recorre a uma analogia - tal como só o ar puro e sereno conduz bem o som também só a poesia clara estabelece a boa comunicação das almas -, cuja pertinência duvidosa nos compete menos ajuizar que analisar; porque, de novo, coloca o problema no âmbito de uma desvalorização do trabalho poético e de uma consideração paradigmática da comunicação imediata. Mas o ponto central é outro: é a afirmação de que a comunicação das almas, quer dizer, os fundamentos de uma efectiva comunidade humana estão lá onde a poesia pode ser mediação. Nesse jogo entre o mistério e o desvelamento, o silencioso e o expresso, - é aí, no que, dessa tensão, pode ser comunicável, que enraíza toda a verdadeira comunidade humana. Este aspecto é importante porque afirma a poesia como efectivo discurso de conhecimento mas principalmente porque nos transporta ao limiar da complexa epistemologia anteriana. $O$ sentimento é uma apreensão do mundo tal como o mundo existe nos indi víduos: é uma inteligibilidade do mundo mediada por esse instrumento que é o homem, o poeta, - é o que há em

(21) Idem, ibidem, p. 97.

(22) Idem, ibidem, p. 100. 
nós de mais irreflectido, mais fatal (ainda que, por outro lado, mais livre)" ( $\left.{ }^{23}\right)$. É, porém, um material que - pela densidade da sua própria ocorrência-sedáà reflexão, à análise: à transformaçãopela inteligência.

Num outro artigo, "A João de Deus", Antero distingue: "osentimento é um - simples - porque é a parte eterna, imutável, divina do homem: o olho com que vemos a Deus, a mão com que lhe palpamos o seio. A inteligência, a fantasia, são complexos, profusos, múltiplos porque são o mutável, o progressivo, a porta por onde nos entra o mundo, o pulmão com que aspiramos e respiramos o universo, o imenso" $\left({ }^{24}\right)$.

Analisar o que existe na sensibilidade é transformar o obscuro em claridade, é conceber uma ideia ("a inteligência forma ideia do sentimento" ${ }^{25}$ ), é abrir caminho à transformação da metáfora em conceito.

Nãoétanto a terminologia que nos interessa, até porqueo vocabulário teórico de Antero é razoavelmente flutuante. O que mais importa é fixar o problema: e esse consiste, num primeiro momento, em conceber a relevância ontológica da arte, a arte como via de acesso d̀ poeticidade do mundo, e, num segundo momento, em estabelecer o confronto entre vários discursos de verdade.

Tal é o objectivo do ensaio "Arte e Verdade". Ainda que o apuro conceptual suscite problemas, trata-se de um texto fundamental para a intelecção do estatuto da arte - ou da experiência estética - como discurso de verdade confrontada com os discursos científicoe religioso.

$\mathrm{O}$ que se chamou sentimento e inteligência, agora designado por novos pares conceptuais (intuição e ideia, inspiração e pensamento), está reduzido a uma unidade essencial. Enquanto o sentimento era a matéria prima da ideia, como vimos, agora "a intuição e a ideia são apenas duas ondas produzidas pelo mesmo impulso, duas vozes da mesma boca, duas expressões do mesmo olhar". Ou, em outra expressão, "a inspiração e o pensamento são os dois eternos combatentes que o homem mandou à conquista do mundo: diferentes são as armas: mas no pendão de ambas está gravada esta mesma legenda: Verdade. A Religião chama-lhe Deus: a Ciência chama-lhe Ideia" $\left({ }^{26}\right)$.

Referidas ao mesmo objectivo, há entre a religião e a ciência uma

$\left({ }^{23}\right)$ Idem, "A João de Deus", in Prosas, vol. I, p. 130.

(24) Idem, ibidem, p. 129.

(25) Idem, ibidem, p. 131.

${ }^{(26)}$ Idem, "Arte e Verdade", in Prosas, vol. I, p. 323. 


\section{A filosofia da Arte de Antero}

simples distinção metodológica. Mas o que a ambas dá sentido, o que a ambas solicitou e pôs em movimento, a voz que a ambas chamou (e sublinho naturalmente a terminologia), - a saber: "o sentimento do infinito", "esse mistério para que todo o olho humano se vira" $\left({ }^{27}\right)$ - é precisamente a condição, por isso inalcançável, de todo o discurso religioso e de todo o discurso científico.

Recordo estas palavras de Mikel Dufrenne: "o mais elevado do pensamento - conhecimento do terceiro género, ideia da razão, saber absoluto - parece-me o mais obscuro, como se o cúmulo do pensamento fosse precisamente a confissão do impensável, uma confissão que não é uma abdicação, onde a razão não dá lugar à fé, mas onde descobre a fé sobre a qual se funda. O impensável não é um certo objecto de pensamento, $e$ antes que o pensamento tenha um objecto e que haja pensamento. Mas é também o que o pensamento pretende pensar: o universalmente verdadeiro, o universo, o Um" $\left({ }^{28}\right)$.

Ora, a religião e a ciência circunscrevem os seus domínios a um ou a outro dos pólos em questão: "uma e outra são exclusivas e estreitas. Uma renega a alma em nome do mundo: a outra o mundo em nome da alma" ${ }^{29}$. E precisamente porque são exclusivas não se dão conta - não podem dar-se conta - do próprio problema de que nascem, da questão em virtude da qual existem: a emergência do pensamento a partir do impensado, o nascimento do discurso a partir do indizível, sem que o impensado e o indizível se esgotem nos discursos de que constituem a condição.

Nesta fase do pensamento de Antero a arteé concebida não só como um discurso de verdade, tal como a religião e a ciência, mas como a obra de uma experiência fundante da própria possibilidade de verdade. Creio que é isto o que Antero indica quando refere que "o grande abraço místico do visível e do invisível não podia ser estéril" $\left({ }^{30}\right)$. Mas a sua produtividade - que é a obra de arte - resulta de uma experiência irredutível às experiências subjacentes aos outros discursos de verdade, irredutível precisamente porque é experiência do caminho mútuo do visível para o invisível.

Sublinhe-se: é um abraço místico, quer dizer, esta experiência
$\left({ }^{27}\right)$ Idem, ibidem, p. 324.
$\left({ }^{28}\right)$ Mikel Dufrenne, Jalons, La Haye, Martinus Nijhoff, 1966, p. 6.
$\left({ }^{29}\right)$ Antero de Quental, ob. cit., p. 326.
$\left({ }^{30}\right)$ Idem, ibidem, p. 325. 
primeira, fundando embora o mais radical de todos os discursos de verdade $\left.{ }^{(31}\right)$, não se explicita nele integralmente. Ser-lhe-à por isso imanente uma tensão entre discurso e silêncio: o que ele, dizendo, dá a ver, é o visível de tudo o que, nessa experiência, pertence ainda à ordem do indizível.

Não admira que Antero pudesse considerar a arte o anúncio de uma nova religião, o discurso da transcendência numa época que antropologizara Deus e acreditara reduzir a misteriosa espessura do mundo. Numa carta a Flórido Teles de Meneses, de 7 de Agosto de 1861, escreve: "a Arte (...) parece-me, a mim que já em bem pouco tenho crenças, a única coisa capaz de ainda poder fazer saltar nos peitos todos os corações capazes de nobremente baterem por alguma coisa boa e bela [:] quem crê na Arte crê no belo, no bom, isto é, no Amor e em Deus, e com estes elementos pode tudo mil vezes mil, que mil vezes será tudo salvo. É por isso, que tantas esperanças ponho na arte: é já um culto antecipado da religião que ainda está por nascer para uma sociedade de que só por aqui terão alguns uma vaga intuição" ( $\left.{ }^{32}\right)$. Interessa-me sublinhar que é pelo motivo de a arte consistir nesse jogo entre o visível e o invisível que constitui uma aproximação da obscuridade, e pode, por isso, afirmar-se como o mais radical dos discursos de verdade, embora não a mais radical experiência de verdade.

Este enunciado transporta-nos a um dos problemas centrais senão o problema fundamental - de Antero. Gostaria de tentar persegui-lo através do artigo "O futuro da música" (1866) e de momentos vários da correspondência, analisados como teorização do fim - talvez seja mais correcto dizer: do esgotamento - da expressividade estética. Quer dizer: desprende-se de estes textos, com muita nitidez, a ideia de que está chegado o momento de a experiência (da poeticidade) do mundo se concretizar num discurso diferente do discurso estético.

Tentaremos perceber, pois isso se me afigura o essencial, se as razões para o fim da música são as razões para o esgotamento da poesia.

"O futuro da música" (1866) é também um ensaio sobre a historicidade da experiência estética e da obra de arte. Para maior

$\left({ }^{31}\right)$ Cf. idem, ibidem, p. 326.

${ }^{(32}$ Idem, Carta a Flórido Teles de Meneses (Coimbra, 7 de Agosto de 1861) in Cartas I, organização, introdução e notas de Ana Maria de Almeida Martins, Lisboa, Universidade dos Açores/ Editorial Comunicação, 1989, pp. 15-16. 


\section{A filosofia da Arte de Antero}

precisão: analisa a linguagem estética requerida pela modernidade ou, para utilizar as suas palavras, "pelo sentimento moderno" $\left({ }^{33}\right)$. Por isso, Antero fica obrigado a um tentame de filosofia da história que apreenda, primeiro, a estruturação interna da modernidade e, depois, a sua finalidade: só este procedimento demonstraria a adequação da música à sua época e explicitaria a relação entre o apogeu da modernidade e $o$ futuro da música.

Assim, "O futuro da música" afigura-se principalmente um capítulo da analítica da modernidade a que Antero se entrega com uma continuidade, pelo menos especulativa, que deve realçar-se. E um traço impressivo dessa analítica é o de a modernidade como interna conflitualidade, responsável pela inscrição no "fundo mesmo da alma moderna" $\left({ }^{34}\right)$ da tensão, não só irredutível mas constituinte, entre o desejo e a descrença, a esperança e a melancolia, a confiança e o desalento.

A modernidade nãoé a simples realização de um espírito geométrico: é um processo onde conflituam as possibilidades libertas pela dissolução dos quadros ideológicos medievais. Digamos de um modo mais próximo da linguagem anteriana: a modernidade permite novas aproximações ao mistério do mundo, de certo modo renovou-o, restituindo-lhe uma outra limpidez, afastada que foi toda a sedimentação explicativa que pretendeu esclarecer esse mistério.

Recordemo-nos de uma observação de Milan Kundera: se no texto cartesiano a modernidade ganha um dos seus contornos clássicos, pelo ideal da ordem, da evidência e da subjectivação, é no texto de Cervantes, e nas personalidades de Quixote e Sancho Pança, que ela encontra as dimensões da aventura, da obscuridade e do senso comum - constituindo a modernidade uma aproximaçãodo mundo internamente articulada por estas duas ordens de razões.

Da óptica de Antero, enquanto a modernidade for precisamente esta tensão, nenhuma outra linguagem a exprimirá melhor do que a música: "os seus dois caracteres mais salientes são feitos para reproduzirem inteiramente aquelas duas expressões, a incerteza audaciosa e a mórbida melancolia" $\left({ }^{35}\right)$. A música é a linguagem do sentimento moderno:

\footnotetext{
$\left.{ }^{(33}\right)$ Idem, "O futuro da música", in Prosas, vol. II, p. 36.

$\left({ }^{34}\right)$ Idem, ibidem, p. 30.

${ }^{35}$ ) Idem, ibidem, p. 35
} 
"reproduzindo os dois caracteres essenciais e originais do espírito novo, e reproduzindo-os não acidentalmente, mas também pelos seus próprios caracteres essenciais, ligou intimamente os seus destinos com os do sentimento moderno, nascidos na mesma hora um para o outro e um pelo outro, caminhando e crescendo dia a dia" $\left({ }^{36}\right)$.

Se o objectivo desta reflexão fosse a concepção anteriana de modernidade, haveríamos de sublinhar agora o seguinte aspecto: a tensão moderna vai resolver-se, a tragicidade que, sem o saber, o pensamento moderno traz na alma será dissolvido pela "crítica (essa química da razão)" ${ }^{(37}$ ) e o conhecimento irá assentar num critério unívoco. A modernidade, no pensamento de Antero, não é por conseguinte um horizonte de certeza, "o ar vital do espírito do homem" $\left({ }^{38}\right)$; é uma longa, "uma ardente procura, uma oscilação entre muitas incertezas igualmente possíveis" ${ }^{39}$ ), é uma "atmosfera ardente, impossível" $\left({ }^{40}\right)$, por isso, destinada à transformação. Incapazes da "respiração do fogo" $\left({ }^{41}\right)$, os homens dispõem, ao fim de três séculos de trabalho lento do laboratório da história, de uma possibilidade da história ("o futuro pertence à confiança, a uma verdade qualquer, não à flutuação, às névoas desta hora que têm que passar por força" $\left({ }^{42}\right)$ : "a análise, a reflexão, a ciência, eis aí o verbo novo. A consciência, na sua constante evolução, passou do estado intuitivo, maravilhoso, para uma fase superior, reflectida, eminentemente positiva e naturalista. Do sentimento subiu-se até à razão: e é dela que se espera agora tudo quanto se estava acostumado a pedir ao vago sentimento, às intuições sublimes mas ilusórias..." $\left({ }^{43}\right)$.

Assim, para o Antero de 1866, a profunda solidariedade entre a música e o sentimento moderno implicará a dissolvente transformação da música no próprio processo de afirmação do elemento racionalista

\footnotetext{
$\left({ }^{36}\right)$ Idem, ibidem, p. 36, subl. meu.

$\left.{ }^{(37}\right)$ Idem, Carta a Jaime de Magalhães Lima (Vila do Conde, 14 de Novembro de 1886) in Cartas II, p. 803.

${ }^{(38)}$ Idem, "O futuro da música", in Prosas, vol. II , p. 40.

$\left({ }^{39}\right)$ Idem, ibidem, p. 39.

$\left({ }^{40}\right)$ Idem, ibidem, pp. 37-38.

(41) Cf. idem, ibidem, p. 38.

(42) Idem, ibidem, p. 40.

(43) Idem, ibidem, p. 42.
} 


\section{A filosofia da Arte de Antero}

moderno. E se a filosofia do futuro - neste momento concebida como o alargamento do legado positivista à metafísica rejeitada por Comte $\left({ }^{44}\right)$ - já não poderá exprimir-se na música é porque essa filosofia permite a reinvenção do homem como peculiar sujeito da história. A indeterminação da música, "linguagem do uno primordial", nas palavras de Nietzsche, haveria de dar lugar, por exigências sociais e políticas, precisamente à determinação de uma sociedade, de uma cultura e de uma arte. É indispensável um esforço, a filosofia do futuro é uma filosofia da vontade - mesmo se o trabalho do filossofo do futuro é a resposta a solicitações que ele não constrói. Como interrogação última, este é o problema que abre o horizonte especulativo de Antero: o problema da subjectividade: quem (o que) é o sujeito (da história, do discurso estético, da linguagem teórica). É possível, como veremos, interpretar as fases de Antero como modulações desta questão central.

O futuro da música não é, porém, o seu fim: é o esgotamento da sua expressividade. Parafraseando o que, a propósito da poesia, Antero escreverá mais tarde, "a música deixou de ter missão social", subsistirá subjectivamente, como "expressão de estados de espírito, ou particulares, ou raros e passageiros" mas terá desaparecido como "agente poderoso de civilização" $\left({ }^{45}\right)$.

É através de um texto contemporâneo de "O futuro da música", refiro-me à "Nota sobre a missão revolucionária da poesia", que pode analisar-se o problema da expressividade - isto é: da voz - das épocas históricas porque é neste texto que a noção de arte fica presa aos imperativos da vontade. Relembro as primeiras linhas do manifesto: "Este livroé uma tentativa, em muitos pontos imperfeita, seguramente, mas sempre sincera, para dar à poesia contemporânea a cor moral, a feição espiritual da sociedade moderna, fazendo-a assim corresponder à alta missão que foi sempre a da Poesia em todos os tempos" $\left({ }^{46}\right)$. Isto

$\left({ }^{44}\right)$ "Não creio que o positivismo um tanto estreito de A. Comte, Littré e da última escola francesa, nos dê completa a filosofia do futuro. Mas se o alargarmos, segundo o espírito do hegelianismo, a ponto de caber nele a metafísica excluída por $\mathrm{A}$. Comte (tendência que já se nota em Taine, Renan e Vacherot e no positivismo inglês de que é chefe Stuart Mill) nesse caso tenho para mim que a filosofia assentará numa base tão sólida, que não será muito aventurar dizer que está achada e definitivamente constituída a filosofia do futuro". (Idem, ibidem, p. 43, nt. 1).

$\left({ }^{45}\right)$ Idem, "A poesia na actualidade", in Prosas, vol II, p. 322.

$\left({ }^{46}\right)$ Idem, "Nota sobre a missão revolucionária da poesia", in Prosas vol. I, p. 306. 
é, desde sempre colocado numa situaçãodefinida por a prioris históricos, pertence à responsabilidade do poeta a escolha de uma das possibilidades que se lhe apresentam. Por isso é que Antero conclui o texto com uma verdadeira tese: "a poesia que quiser corresponder ao sentido mais fundo do seu tempo, hoje, tem forçosamente de ser uma poesia revolucionária" $\left({ }^{47}\right)$.

Sublinho: a poesia que quiser corresponder. Subsiste, como possibilidade, embora desfasada, do seu tempo, a hipótese de uma poesia confessional, subjectiva - mas dessa equívoca subjectividade que pressupõe o individualismo e não a comunidade. A solidariedade entre as noções de poesia revolucionária e de voz - "a Poesia moderna é a voz da Revolução" - assenta, como já foi dito, num desejo de comunicabilidade imediata, fundada, por sua vez, na matriz evangélica e ecuménica do projecto de revolução e de futuro defendido por Antero. Desta relação intrínseca que defende a poesia revolucionária como voz do Progresso, irá Antero mais tarde libertar-se. Mas importa agora sublinhar que o pressuposto desta poesia revolucionária, o de que há um pensamento que desvenda o sentir mais fundo de uma época histórica e que habilita os homens à reconstrução do mundo humano, éo primeiro momento da desconstrução de uma concepção politicamente optimista do discurso poético. A arte, de que, em "Arte e verdade" tentará sublinhar-se o carácter positivo, é-o em confronto com a ciência e a religião. É porém à ciência positiva, à ciência da natureza "a natureza penetrada, revelada pelo pensamento" $\left({ }^{48}\right)$ que Antero alude: isto é, a uma particular realização do discurso teórico.

O empenhamento cívico e político - primeiro, no âmbito da Questão Coimbrã, e depois, nas Conferências do Casino e suas consequências - poráa prova a eficácia, ou melhor, o limite do discurso poético como discurso político. As vicissitudes por que passa a elaboração do Programa para os trabalhos da geração nova, amadurecido longamente e integralmente destruído em 1875, e a decisão (sublinho: a decisão) de abandonar a escrita poética, dez anos depois, em 1885, reconstroem um problema: é possível falar do mistério do mundo? o mistério do mundo é da ordem do dizível? qual é a experiência essencial do mistério do mundo?

\footnotetext{
$\left({ }^{47}\right)$ Idem, ibidem, p. 314 .

${ }^{48}$ Idem, "Arte e verdade", in Prosas, vol. I, p. 326.
} 


\section{A filosofia da Arte de Antero}

Se é esta a interrogação, notamos que a música evocativa, esgotada porque (já) lhe não responde, dá lugar ao poder de determinação da palavra poética, por sua vez erodido pela eficácia da filosofia (política, prática). Ao fundo trágico, e não tanto contraditório, do pensamento de Antero, devemos a circunstância de nenhum de estes passos constituir a síntese dos anteriores mas a reorganização de elementos obsessivamente recorrentes.

O Programa quer preencher um vazio teórico-especulativo - a insuficiência da praxis como meio de transformação do real $\left({ }^{49}\right)$ - mas o seu abandono e destruição poderá traduzir precisamente a intuição (por enquanto só intuição) de que o que é transformável pela praxis não pertence à ordem do essencial. Mesmo que seja mais prudente não levar à conta de tese o desabafo de Antero numa carta a Alberto Osório de Castro - "a política nunca foi muito para os poetas, hoje e entre nós menos que nunca. Creio que fez muito bem em abandonar esse campo lamacento" $\left({ }^{50}\right)$ - é possível que o empenhamento político de Antero, independentemente da consciência que o poeta dele pudesse ter tido, jamais se tenha desligado, na sua atitude teórica e existencial, de um contraponto contemplativo, místico.

Referida a esta tensão essencial entre a acção e a contemplação é que poderá tomar-se o seu pensamento sobre a arte - apogeu, crise e substituição por outras formas de referência ao real - pois nela, mais doque em qualquer destas, é que existem, comoelementos constituintes, os jogos múltiplos da acção e da contemplação.

O exame de dois textos em que Antero reflecte teoricamente sobre a poesia elucida-nos acerca do que está em causa na transformação do seu pensamento sobre o tema. Refiro-me a "Tendências novas da poesia contemporânea" e "A poesia na actualidade". Publicados, o primeiro em 1871, e o segundo em 1881, estão separados por uma década decisiva na evolução espiritual de Antero. E, embora provocados por obras mais ou menos esquecidas (Radiações da noite de Guilherme de Azevedo e Lira íntima de Joaquim de Araújo), o interesse das considerações subsiste.

$\left({ }^{49}\right)$ Cf. Fernando Catroga, "A metafísica indutiva de Antero Quental", Biblos, vol. LXI, 1985, pp. 472-507 e Joel Serrão, Antero e a ruína do seu Programa(1871 - 1875), Lisboa, Livros Horizonte, 1988.

$\left({ }^{50}\right)$ Idèn, "Tendências novas da poesia contemporânea", in Prosas, vol. II, p. 197. 


\section{Antero de Quental}

O primeiro texto constitui uma defesa da arte nova, uma poesia de combate na qual "a inspiração social e naturalista vem substituir a sentimentalidade toda subjectiva e pessoal, ou o transcendentalismo contemplativo de outras idades poéticas". E acrescenta: "a poesia deixa de duvidar e cismar, para afirmar e combater; mostra-nos o interesse profundo e o valor ideal dos factos de cada dia; dá às acções, que parecem triviais, da vida ordinária um carácter e significação universais $\left({ }^{51}\right)$.

Mas esta doutrina decorria de uma decisão anterior mais profunda. Antero formulara as perguntas seguintes: "não será uma sociedade essencialmente anti-poética, esta nossa, um mundo rebelde a toda a idealidade? Por outras palavras; poderá haver poesia racional, positiva, social? Será um ser poético o homem do nosso tempo?" $\left({ }^{52}\right)$ A resposta é positiva e por issoé que uma poesia de combate é poesia. Porém, aqui, é a pergunta que nos interessa, e não a resposta. Porque, exprimindo-nos em linguagem diferente, o que Antero quer é saber se é possível uma experiência poética que não seja uma simples experiência subjectiva, isto é, se é possível uma experiência da poeticidade do mundo $\left({ }^{53}\right)$ e se a sua expressão estética é a obra poética?

Dez anos volvidos, Antero distingue com maior rigor estes dois planos. Na sua própria terminologia é o que nos diz quando observa que a poesia vai persistir mesmo depois do esgotamento do poético: o poetar continua após o desaparecimento da poesia.

A recordação de um passo, embora extenso, é importante $\left({ }^{54}\right)$ para nos autorizar a duas conclusões. A primeira: embora a tensão especulativa em que Antero se movimentou aponte permanentemente

${ }^{(51)}$ Idem, Carta a Alberto Osório de Castro (Lisboa, 25 de Novembro de 1890) in Cartas II, p. 1013.

(52) Idem, ibidem, p. 96.

$\left.{ }^{(53}\right)$ Aludo à categoria central da reflexão de Mikel Dufrenne que recuperou a noção espinosista de natureza naturante para significar a identificação poética da Natureza: "podemos determinar a Natureza como fundo dessa energia que faz surgir as palavras e as coisas como estranhas figuras resplandecentes à superfície, animadas por esse fundo". Cf. o breve desenvolvimento tentado em: António Pedro Pita, O poético e os saberes, Coimbra, Oficina do CES, 1991.

$\left({ }^{54}\right)$ "A poesia deixou de ter missão social. Os raros poetas, que ainda existem, são apenas os restos destroçados duma raça de outras idades e que breve terá desaparecido.

A poesia passou decididamente à categoria de literatura amena - ao lado da teologia, outra espécie também de literatura, com a diferença de ser mais enfadonha. 


\section{A filosofia da Arte de Antero}

para mais longe, é a missão social que constitui, mesmo para o olhar crítico de 1881, a maior radicalidade da escrita poética; quer dizer, embora a arte (a música, a poesia) esteja investida de um poder de revelação jamais infirmado, e assim suspensa sobre um alcance ontológico, é aqui reduzida ao plano empírico.

Por esta via, e será a segunda conclusão, é que Antero se impede a si mesmo de compreender que a transformação da poesia em objecto de discurso poético não é o sinal do seu fim mas precisamente o sinal da sua valorização ontológica e não simplesmente empírica. Por outras palavras: Antero colhe, em Lamartine, o ensinamento da secularização da poesia e dela fará o fundamento de uma poética de combate que seja expressão simultânea de um empenhamento cívico. Todavia, no poeta francês, havia mais, havia outra coisa: "com Lamartine, a poesia torna-se ao mesmo tempo o objectivoe o objecto da poesia, se se compreendeu bem que isto não implica nenhum esteticismo nem nenhum narcisismo. É a nova condição da poesia: que ela não tenha de momento outra missão, ou outra solução, que a de procurar-se, meditar-se, fora de toda a estética instituída e de toda a vontade principalmente estética" $\left({ }^{55}\right)$.

Antero, no horizonte de sociabilidade que identificou com a finalidade da poesia, fará do processo de objectivação uma interpretação apocalíptica: "esse inevitável egotismo, este retirar-se da matéria poética objectiva da esfera da poesia, é a prova do seu fim próximo" $\left({ }^{56}\right)$. Por isso, enquanto, no trilho de Lamartine, a autonomia do

\footnotetext{
Resquiescant in pace.

Quererá isto dizer que a poesia ou pelo menos o poetar tenha de desaparecer completamente?

Não é esse o meu pensamento. Mas afigura-se-Ine que ficará reduzida à expressão isolada de sentimentos muito pessoais e muito limitados, e cultivada e amada só por aquelas pessoas, que, ou permanentemente e por natureza, como as mulheres, ou temporariamente, como os rapazes muito moços e dotados de alguma fantasia, reagem contra a tirania da reflexão e tendem a isolar o seu mundo de sentimentos da influência mortal do espírito analítico e positivo.

A alta poesia, épica, trágica, lírica-essa irmã da metafísica e da religião-terá assim desaparecido mas subsistirá a poesia subjectiva, familiar e pessoal, como expressão de estados de espírito, ou particulares ou raros e passageiros.

A poesia conservar-se-à pois, mas tendo perdido o antigo carácter de uma das grandes forças sociais e espirituais da humanidade, de agente poderoso da civilização". (Antero de Quental, "A poesia na actualidade" in Prosas, vol. II, pp. 321-322).

$\left({ }^{55}\right)$ J.-M. Gleize, ob. cit., p. 22.

$\left({ }^{56}\right)$ Antero de Quental, ob. cit., p. 318.
} 
poético era condição da maior complexidade da sua natureza social e ontológica, para Antero era o simples subjectivismo. Escrever poesia (e não, simplesmente, poetar) deixava, em rigor, de ter sentido.

$\mathrm{Na}$ correspondência, pelo menos desde 1883 (dois anos antes de decidir deixar de escrever poesia), surpreendemos a expectativa da situação. Em carta a António Lopes dos Santos Valente, alude a "minha poesia que entrou agora numa nova fase, mais serena e larga, ainda que de fôlego curto, pois só produz um ou outro raro soneto; - mas esses, ao menos, já não causam pesadelos a quem os lê". E depois: "quando se esgotar este último veio poético e se fechar o meu ciclo conto reunir os meus Sonetos Completos. Afinal, é tudo quanto de mim sobrenadará - se bem os julgo e se bem me julgo" $\left({ }^{57}\right)$. De igual modo, numa carta que acompanha a oferta de um soneto, o depois célebre "Na mão de Deus, na sua mão direita", Antero deixa uma referência ao esgotamento da "veia do soneto, que já declina sensivelmente" $\left({ }^{58}\right)$.

$\mathrm{Na}$ referida carta a Santos Valente, contudo, existem dois outros elementos que requerem valorização. $O$ primeiro, a saber: a ideia de que o conjunto dos sonetos compõe uma autobiografia, encontramo-lo reafirmado em outras cartas: os sonetos "constituem uma espécie de Autobiografia psicológica, ou de Memórias morais, que, pelo menos como documento, terá o seu interesse" $\left({ }^{59}\right)$; "uma espécie de autobiografia poética, ou de Memórias morais e psicológicas" $\left({ }^{60}\right)$; "espécie de autobiografia psicológica que pelo menos valerá como documento, pois nela está retratada uma evolução intelectual e sentimental, as 'memórias duma alma' para falar com estilo de Lamartine" ( $\left.{ }^{61}\right)$. É desnecessário acumular estas referências. Mas importa acrescentar que a escrita deste sujeitoreal, cujo desenvol vimento empírico, existencial, é testemunhado pelos sonetos - "o testamento do

${ }^{(57)}$ Idem, Carta a António Lopes dos Santos Valente (Vila do Conde, 15 de Fevereiro de 1883) in Cartas II, p. 656.

$\left({ }^{58}\right)$ Idem, Carta a Joaquim de Araújo (Vila do Concle, 17 de Junho de 1883) in Cartas II, p. 668.

$\left({ }^{59}\right)$ Idem, Carta a António Lopes dos Santos Valente (Vila do Conde, 2 de Março de 1885) in Cartas II, p. 727.

$\left({ }^{60}\right)$ Idem, Carta a Francisco Machado Faria e Maia (Vila do Conde, 28 de Março de 1885) in Cartas II, p. 730.

${ }^{(61)}$ Idem, Carta a António de Azevedo Castelo Branco (Vila do Conde, 6 de Junho de 1885) in Cartas II, p. 742. 
pobre poeta que acabou" $\left({ }^{62}\right)$ - está essencialmente referida a um plano radicalmente diferente do plano empírico. De certo modo, a escrita poética anteriana é, como vimos, por princípio e de facto um modo de desvelamento, dá a ver, e é, neste sentido, um dispositivo que emite imagens para um outro, um dispositivo de comunicação. Como todavia observa o próprio Antero, o conjunto dos sonetos "será a autobiografia poética dum sonhador, dum crente? - crente em quê? - no invisível, no insondável, no que não é esta miserável existência real, que evidentemente não pode ser o que parece, porque então o Universo seria absurdo" $\left({ }^{63}\right)$.

É precisamente o segundo aspecto que pretendo sublinhar. A autobiografia de um crente no invisivel coloca-nos de imediato no limiar de uma bifurcação extremamente sugestiva: enquanto crença no invisivel, transporta-nos do registo real para o espaço ideal da possibilidade; mas enquanto crença confere à possibilidade a importância de um verdadeiro fundamento transcendental $\left({ }^{64}\right)$. Pode dizer-se qua a palavra vem dizer "mais do que ela dizia antes, mais do que ela vinha dizer" $\left.{ }^{65}\right)$. Por ela, não desconhecemos só a identidade do objecto finalmente revelado mas também o percurso para o atingir ${ }^{66}{ }^{6}$ : e é exactamente o efeito desta revelação sobre o próprio poeta que nos pode permitir compreender o passo seguinte do seu trajecto espiritual.

Recordemos estas palavras de Gaston Bachelard: "a imaginação não é, como o sugere a etimologia, a faculdade de formar imagens da realidade; $e ́$ a faculdade de formar imagens que ultrapassam a realidade. É uma faculdade de superhumanidade. Um homem é um homem na proporçãoem queé um superhomem". Eestas, que lhe dão continuidade: "a imaginação inventa mais do que coisas e dramas, inventa vida nova.

${ }^{(62}$ Idem, Carta a Carolina Michaëlis de Vasconcelos (Vila do Conde, 7 de Agosto de 1885) in Cartas II, p. 748.

$\left({ }^{63}\right)$ Idem, Carta a António Lopes dos Santos Valente (Vila do Conde, 15 de Fevereiro de 1883) in Cartas II, p. 656.

$\left({ }^{64}\right)$ A filosofia de Antero como movimento para o transcendental encontrou a sua interpretação mais explícita em: FernandoCatroga, "Ooptimismo transcendental" , JL - Jornal de Letras, Artes e Ideias, n. ${ }^{\circ} 466,11$ de Junho de 1991.

$\left({ }^{65}\right)$ Jean Burgos, Pour une poétique de l'imaginaire, Paris, Editions du Seuil,1982, p. 10 (subl. meu).

${ }^{(66)}$ Cf. Idem, ibidem, p. 10. 
inventa espírito novo; abre olhos que têm tipos novos de visão. Verá se ela tem "visões". Terá visões se se educar com devaneios ["rêveries"] antes de educar-se com experiências, se as experiências vierem em seguida como provas dos seus devaneios" $\left({ }^{67}\right)$.

Talvez pela incompreensão relativa ao processo de valorização ontológica da palavra poética, em curso nessa modernidade que Lamartine poderá ter intuído, Antero acaba por insatisfazer-se da escrita poética pelo motivo de que ela se lhe afigurava não dispor dos meios adequados aos seus fins.

Suponho que o texto mais claro relativo a este movimento interno do seu pensamento é uma carta a Carolina Michaëlis de Vasconcelos, de 7 de Agosto de 1885. Importa tê-lo presente, apesar da sua extensão $\left(^{68}\right)$, para restituir ao contexto o seu momento chave: a transição da imagem para o pensamento, o reconhecimento de que a

$\left({ }^{67}\right)$ Gaston Bachelard, L'eau et les rêves, Paris, Librairie José Corti, 1981, pp. 23-24.

${ }^{\left({ }^{6}\right)}$ "Há mais de 20 anos que faço Sonetos, e todavia nunca escolhi esse género nem estudei nos mestres os segredos especiais daquela forma; levou-ma para ali uma predileç̧ão impensada e singular (pois, quando comecei, ninguém entre nós os fazia já, sepultados como estavam, com todas as outras formas clássicas, debaixo da reprovação dos românticos) e talvez a influência dos nossos poetas do século XVI, que foram dos primeiros que conheci. O fundo de idealismo que há naqueles poetas apossou-se então de mim e os seus Sonetos, especialınente os de Camões, tornaram-se para mim como um Evangelho do sentimento. Tais são as minhas raízes, se assim posso dizer. Depois li muitos poetas, e naturalmente muitos Sonetos (como os de Miguel Ângelo, os de Filicaia, os de Gérard de Nerval, e alguns de Milton e Shakespeare), mas sem preocupação alguma de género ou escola, nem sobretudo de estudo. Lia, porque precisava ler, voilá tout: Homero e os Niebelungen em traduções francesas; Goethe e Heine, Dante, Shakespeare, Byron, os Romanceiros espanhóis, no original. Com isto, naturalmente, muita outra coisa, antiga ou moderna, boa e má, porque a minha curiosidade era grande: mas, torno a dizê-lo, tudo isto mal e à la diable, na confusão e no tropel dum espírito agitado por problemas que a poesia só por si não podia resolver. Nos mesmos poetas, era o fundo mais do que a forma que me atraía. Mas, na minha impaciência, na minha impetuosidade, saltava dali e a linguagem abstrusa, o formalismo, a extraordinária abstracção de Hegel não me assustavam nem repeliam; pelo contrário: internava-me com audácia aventureira pelos meandros e sombras daquela floresta formidável de ideias, como um cavaleiro andante por alguma selva encantada à procura do grande segredo, do grande fétiche, do Santo Graal, que para mim era a Verdade, a verdade pura, estreme, absoluta... Era uma grande ilusão, como todos os Santos Graais: mas essa ilusão me levou gradualmente da imagem para o pensamento, fez-me sondar o que toda a alta poesia pressupõe, mas esconde tanto quanto revela, e - para quê encobrir esta minha velha e inveterada pretensão? - fez de mim um Filósofo! Um filósofo manqué, talvez, porque, afinal, ainda não revelei ao 


\section{A filosofia da Arte de Antero}

possibilidade especulativa da linguagem poética tem um limite, que não é uma limitação exterior mas um limite interno inevitável na concepção anteriana de linguagem (e imagem) poética, e a conviç̧ão de que só a linguagem filosófica poderia superá-lo e, por isso, adequar o meio à finalidade.

Se tomarmos como referência o ciclo de sonetos $A$ ideia, em particular o último - "Lá! Mas onde é lá? aonde? - Espera" - o problema é o de saber em que linguagem esse lá deixa dizer-se. Por outras palavras, a insatisfação de Antero radica, por um lado, no pressuposto de que a palavra poética designa e, por outro, na progressiva convicção de que o saber não é produzido por um dispositivo de designação mas por um dispositivo de demonstração: há uma incompatibilidade fundamental entre o discurso analítico e o discurso simbólico. É este o ponto de partida do Antero da década de 80: "como se da filosofia, da ciência e da história fosse possível extrair o que elas não contêm! como se a acumulação da análise pudesse produzir o contrário da análise, um símbolo plástico, uma intuição poética! Eu também acreditei nisso alguma hora, como acreditei em muitos outros dogmas da moderna superstiçãa do Progresso" $\left({ }^{69}\right)$.

Ao discurso poético está, pois, vedada a presença mesma da coisa. Uma afirmação da modernidade como: "a palavra é a ausência da coisa" - o "sacrifício da coisa" diz Hegel $\left({ }^{\circ}\right)$ bem como a concepção de imagem como a de Maurice Blanchot - "a imagem, no poema, não é a designação de uma coisa, mas a maneira como se realiza a posse dessa coisa ou a sua destituição, o meio que o poeta encontra para viver com ela. Nesta presença nova a coisa perde a sua individualidade de objecto fechado pelo uso, tende a metamorfosear-se em qualquer outra coisa e em todas as coisas, de modo que a imagem primeira e, também

mundo o meu Apocalipse, nem sei se chegarei a revelá-lo... Mas, em todo o caso, pretensão ou realidade, o certo é que o filósofo, que por muito tempo só se exprimiu pela boca do poeta, acabou por confiscar, por absorver, por devorar o pobre poeta, e agora que este acabou, impõe-se ao filósofo (para não passar por um assassino gratuito e aleivoso) a obrigação de ser gente por si só e de falar pela própria boca." (Idem, Carta a Carolina Michaëlis de Vasconcelos (Vila do Conde, 7 de Agosto de 1885) in Cartas II, p. 748).

$\left({ }^{69}\right)$ Idem, "A poesia na actualidade", in Prosas, vol. II, p. 318.

${ }^{\left({ }^{0}\right)}$ António Ramos Rosa, A poesia moderna e a interrogação do real-I, Arcádia, Lisboa, 1979, p. 35. 
ela, conduzida a mudar e, impelida no ciclo das metamorfoses, torna-se sem cessar um poder mais complexo e mais forte que transforma 0 mundo pela apropriação do desejo" $\left({ }^{1}\right)$ - constituem, vistas da óptica de Antero, não tanto o sinal da afirmação ontológica da palavra poética mas antes o reconhecimento da sua inefić́cia essencial.

É em resposta a este sentimento, como se sabe, que Antero redige os seus dois textos filosóficos mais elaborados, $A$ "filosofia da natureza" dos naturalistas (1885) e Tendências gerais da filosofia na segunda metade do século XIX (1890). A confissão de que um e outro não são ainda $o$ Livro - obsessivamente reafirmada em vários passos da correspondência-permite colocar-nos, por último, o próprio problema do limite interno da escrita filosófica.

Porque é, em derradeira instância, para a inefićácia de toda a escrita considerada como discurso de uma verdade pensada como presença que nos remete o misticismo - activo, científico - de Antero. Este misticismo, primeiro, assenta numa dissolução da subjectividade, que é mais aspiração à Unidade que efeito pluralizador: "a nossa vida, meu João, verdadeiramente, é só a vida da nossa alma, do misterioso e sublime eu que somos no fundo: ora esse eu ou essa alma tem a sua esfera na região do impessoal: o seu mundo é o de abnegação, da pureza, da paciência e do contentamento: na renúncia do indivíduo natural e de tudo quanto o limita, algema e obscurece é que consiste a sua misteriosa individualidade" $\left({ }^{2}\right)$. E, depois, solidifica-se por meio da assumpção existencial da filosofia, isto é, pela sua relativa desvalorização como discurso categorial: "a Filosofia, começando pela inteligência, acaba por entrar no coração apossando-se dele e da vida toda, como de coisa sua" $\left({ }^{73}\right)$.

A ressalva de que não reduz toda a fillosofia à moral, feita na mesma carta, não impede a possível deteç̧ão do problema que avassala

("1) Maurice Blanchot, La part dufeu, pp. 114-115 (cit. A. R. Rosa, ob. cit., p. 35); cf. idem, "Les deux versions de l'imaginaire" in L'espace littéraire, col. Idées, Paris, Gallimard, 1973, pp. 341-359.

$\left({ }^{72}\right)$ Idem, Carta a João Machado de Faria e Maia (Vila do Conde, 12 de Agosto de 1884) in Cartas II, p. 710.

$\left({ }^{73}\right)$ Idem, Carta a J. M. de Faria e Maia (Vila do Conde, 28 de Março de 1885) in Cartas II, p. 729. 
Antero. Na carta a Oliveira Martins em que anuncia as Tendências gerais, observa: "ficou reservada muita coisa que naturalmente não cabe em artigos de Revista. Escuso de dizer-lhe que não é a minha filosofia, aquela que $\mathrm{V}$. sabe que eu tenho, com o seu método próprio e teorias particulares. Essa, infelizmente, desisto de a expôr, porque está acima das minhas forças o fazê-lo - e depois ninguém me entenderia" $\left({ }^{4}\right)$.

Dificuldade material, certamente, de fazer caber nos limites (sempre) estreitos de uma revista a reflexão amadurecida de uma vida de pensamento. Mas, porque é exactamente de uma tarefa vital que falamos, dessas em que a vida se examina para (re)construir-se, é possível que a dificuldade seja de outra ordem, intrínseca ao discurso filosófico: nas já referidas palavras de Mikel Dufrenne, "como se o cúmulo do pensamento fosse precisamente a confissão do impensável".

$\left({ }^{74}\right)$ Idem, Carta a Oliveira Martins (Vila do Conde, 26 de Novembro de 1889) in Cartas II, p. 966. 